\title{
TANTANGAN ETIK PADA PERAWAT DALAM PENANGANAN PASIEN DI MASA PANDEMIK COVID-19: SCOPING REVIEW
}

\author{
Imran Pashar ${ }^{1}$, Suhartini Ismail ${ }^{2 *}$, I Edward ${ }^{3}$, Sarinti $^{4}$ \\ ${ }^{1}$ Mahasiswa Magister Keperawatan Departemen Ilmu Keperawatan Universitas Diponegoro. \\ ${ }^{2}$ Divisi Keperawatan Gawat Darurat Departemen Ilmu Keperawatan \\ Fakultas Kedokteran Universitas Diponegoro. \\ ${ }^{3}$ Departemen Kedokteran Umum Fakultas Kedokteran Universitas Diponegoro. \\ ${ }^{4}$ Perawat Intensive Care Unit, Rumah Sakit Tugurejo. \\ *) suhartini.ismail@fk.undip.ac.id
}

\begin{abstract}
Abstrak
Tantangan etik mengacu pada dilema etika dan konflik etika serta skenario lain yang membuat perawat berada pada pilihan yang sulit. Tujuan dari review adalah untuk meringkas bukti dari tantangan etik pada perawat dalam penanganan pasien di masa pandemik COVID-19. Artikel ini dirancang menggunakan metode scoping review. Pencarian artikel dilakukan menggunakan data base dari Sciencedirect, Scopus, EBSCO, dan ProQuest yang terbit dalam pada bulan Januari sampai September tahun 2020 dengan kata kunci "COVID-19" AND "Nurse" AND "ethic challenges" OR "Issue Ethic" OR "Dilemma ethic. Munculnya berbagai masalah terkait etik dalam praktik perawatan pasien COVID-19 membuat perawat mengalami lebih banyak kesulitan, tanggung jawab dan tantangan akibatnya berdampak terhadap kualitas pelayanan didalam ruang perawatan intensif dan isolasi. Hasil penelitian ditemukan 3 tema, yaitu 1) tanggung jawab perawat, 2) tantangan etik selama perawatan, 3) beban kerja selama perawatan. Kesimpulan review adalah Tantangan etik yang dihadapi perawat selama perawatan di masa pandemik COVID-19 yakni pasien dengan COVID-19 yang berbeda penanganannya dengan pasien lainnya, terdapatnya ketidaksetaraan, tingginya tuntutan etika professional, dan kompetensi kerja yang berubah-ubah. Selain itu hak pasien yang terlupakan, kurang perhatian pada etik professional dan perawat selalu dihadapkan pada situasi yang membingungkan.
\end{abstract}

Kata kunci : Pandemik COVID-19, perawat, tantangan etik

\begin{abstract}
Ethical challenges are common in clinical nursing practice. Ethical challenges refer to ethical dilemmas and ethical conflicts, and other scenarios where nurses make difficult choices. The review aims to summarize the evidence of nurses' ethical challenges in handling patients during the COVID-19 pandemic. This article is designed using the scoping review method. The search for articles was carried out using a database from Science Direct, Scopus, EBSCO, and ProQuest published in January to September 2020 with the keywords "COVID-19" AND "Nurse" AND "ethic challenges" OR "Issue Ethics" OR "Dilemma ethic. The emergence of various ethical issues in caring for COVID-19 patients has made nurses experience more difficulties, responsibilities, and challenges due to which has an impact on the quality of service in intensive care and isolation rooms. The results found three themes, namely 1) nurse responsibility, 2) ethical challenges during treatment, 3) workload during treatment. This review's conclusion is the ethical challenges faced by nurses during care during the COVID-19 pandemic, namely patients with COVID-19 who are different from other patients, there are inequalities, high demands for professional ethics, and changing work competencies. Besides that, the patient's rights are forgotten; there is a lack of attention to professional ethics, and nurses are always faced with confusing situations.
\end{abstract}

Keywords: COVID-19, ethical challenges, nurse, pandemic 


\section{Pendahuluan}

Meningkatnya jumlah penyebaran penyakit yang diakibatkan oleh virus COVID-19 yang telah ditetapkan sebagai pandemi oleh WHO pada tanggal 12 Maret 2020 (World Health Organization, 2020a). Kewaspadaan standar harus selalu diterapkan di semua fasilitas pelayanan kesehatan dalam memberikan pelayanan kesehatan yang aman bagi semua pasien dan mengurangi risiko infeksi lebih lanjut (Kementerian Kesehatan Republik Indonesia, 2020). Tim perawatan kritis setiap harinya menghadapi masalah etik dalam memberikan aktifitas asuhan yang profesional. Perawat dan semua anggota tim pelayanan kesehatan, harus melindungi integritas personal dirinya dan rasa keadilan agar dapat efektif dalam bekerja. Seringkali perawat ditekan untuk dapat mengelompokkan emosi - emosi dengan cepat dan tabah demi melakukan kewajibannya (Jameton, 2017; van Nistelrooij \& Leget, 2017). American Association of Critical Care Nurse menegaskan bahwa setiap institusi harus menerapkan dengan sumber-sumber yang dapat diakses untuk mengidentifikasi dan memitigasi efek buruk dari distress moral. Dalam hal ini, perawat tidak boleh ragu ragu untuk mencari dukungan etik yang profesional dan berbagai macam konseling ketika mengalami moral distres atau merasa kehilangan integritas personalnya (AACN Position Statement, 2015).

Pandangan tentang situasi kesehatan masyarakat yang luar biasa disebabkan oleh pandemi COVID-19 menjadikan alokasi sumber daya atau prioritas pengobatan menjadi elemen penting untuk memiliki kerangka acuan etis agar dapat membuat keputusan klinis yang sesuai (Rubio et al., 2020). Muncul berbagai masalah seperti ketegangan antara hak petugas kesehatan untuk perlindungan dan kewajiban selama proses pengobatan, lonjakan kasus COVID-19 (Markwell, Mitchell, Wright, \& Brown, 2020). Muncul tantangan etik utama bagi petugas kesehatan selama pandemi COVID-19 yang teridentifikasi yakni adanya isolasi sosial, tugas perawatan dan akses yang dituntur adil selama pengobatan. Selain itu diperlukan relasional otonomi dan solidaritas dieksplorasi dalam kaitannya dengan isolasi sosial. Tantangan etik adalah hal yang umum terjadi dalam praktik keperawatan klinis (Rushton, 2016; Strandås \& Fredriksen, 2015). Tantangan etik mengacu pada dilema etika dan konflik etika serta skenario lain di mana 
harus ada pilihan yang sulit (Larkin et al., 2019). Pengaturan prioritas dan akses ke pengobatan meningkatkan masalah etika yakni kesulitan yang dihadapi dalam setiap proses pengambilan keputusan, terkait pengobatan yang diakan dilakukan (Jeffrey, 2020). Masalah yang biasa terjadi dalam praktik keperawatan klinis, dan lingkungan dengan penyakit menular yang membuat perawat menghadapi tantangan etika sehingga menyebabkan perawat mengalami tekanan hingga mengarah pada sikap negatif, sulit mengontrol emosi dan tekanan psikologis yang berisiko merusak kesehatan mental perawat (Jia et al., 2020).

\section{Selama pandemi COVID-19,} perawat menghadapi situasi yang rumit dan tidak pernah mereka temui sebelumnya sehingga kemungkinan mengalami berbagai masalah/tekanan. Salah satu penyebabnya karena kebijakan kunjungan rumah sakit yang sangat terbatas yang mencegah perawat melibatkan keluarga dalam keputusan perawatan, langkah-langkah isolasi yang dapat mengakibatkan pasien sekarat tanpa kehadiran keluarga secara fisik, mengalami kelelahan karena beban kerja dan perubahan jadwal kerja, terdapat kekhawatiran terhadap kesehatannya sendiri, kurangnya penyediaan alat pelindung diri dan peralatan medis lainnya (AACN Position Statement, 2015).
Perawat harus mempunyai kemampuan yang baik untuk pasien maupun dirinya didalam menghadapi masalah yang menyangkut etik. Seseorang harus berpikir secara rasional, bukan emosional dalam membuat keputusan etik. Keputusan tersebut membutuhkan keterampilan berpikir secara sadar yang diperlukan untuk menyelamatkan keputusan pasien dan memberikan asuhan. Kemampuan membuat keputusan masalah etik menjadi salah satu persyaratan bagi perawat untuk menjalankan praktik keperawatan professional (Haryono, 2012). Ditemukan berbagai artikel terkait tantangan etik perawat yang terjadi selama penanganan pada pasien COVID-19 . Scoping review ini bertujuan untuk meringkas bukti dari tantangan etik pada perawat dalam penanganan pasien di masa pandemik COVID-19.

\section{Metode}

Artikel ini menggunakan kerangka metodologi oleh Arksey dan O’Malley dalam melakukan scoping review. Metode yang digunakan ini ada lima langkah yang harus dilakukan antara lain mengidentifikasi pertanyaan penelitian secara jelas dan obyektif; mengidentifikasi artikel yang relevan; pilihan literature terkait dari artikel dan ekstrasi data; pengorganisasisan, meringkas, dan 
menganalisis; melaporkan hasil data.

Pertanyaan pada artikel ini yaitu

\section{Hasil}

"Bagaimana tantangan etik pada perawat dalam penanganan pasien di masa pandemik COVID-19?”. Pencarian literature terkait menggunakan data based dari Sciencedirect, Scopus, EBSCO, dan ProQuest. Artikel yang relevan dengan topik pada bulan Januari sampai September tahun 2020. Dalam pencarian literatur dengan menggunakan Booleon operators "OR/AND". Kata kunci yang digunakan dalam pencarian: ("COVID-19" AND "Nurse" AND "ethic challenges" OR "Issue Ethic" OR "Dilemma ethic). Artikel yang digunakan dalam pembuatan scoping review ini terkait tantangan etik pada perawat dalam penanganan pasien di masa pandemik COVID-19 dan di publikasikan pada bulan Januari sampai Agustus 2020. Literature yang digunakan menggunakan bahasa Inggris. Partisipan dalam artikel yang di review yaitu perawat yang menangani pasien COVID-19. Artikel yang tidak bahas Inggris, casestudy, report dikecualikan. Ditemukan 298 artikel dari hasil pencarian, dan berdasarkan kriteria inklusi maka didapatkan 10 artikel terdiri dari 4 artikel kuantitatif dan 6 artikel kualitatif yang akan dilakukan analisis.

Secara keseluruhan, 10 artikel memenuhi kriteria inklusi dan telah dianalisis lebih lanjut. Artikel dalam review ini terdiri dari metode kualitatif ( $\mathrm{n}$ =6) dan kuantitatif $(\mathrm{n}=4)$ yang dilakukan pada masa pandemik COVID-19 terkait tantangan etik yang dihadapi tenaga medis yakni salah satunya adalah perawat. Studi penelitian tersebut telah sesuai dengan topik terkait tantangan etik pada perawat dalam penanganan pasien di masa pandemik COVID-19. Berdasarkan hasil analisis yang telah dilakukan ditemukan 3 tema yakni tanggung jawab perawat, tantangan etik selam perawatan dan beban kerja selama perawatan

\section{Tema 1 : Tanggung Jawab Perawat}

Terdapat 2 studi yang membahas mengenai bentuk tanggung jawab perawat yang harus terpenuhi selama proses perawatan. Studi tersebut menggunakan metode kualitatif $(n=2)$ yang terdiri dari 1 studi di lakukan di Iran dan 1 studi dilakukan di Cina. Penelitian yan dilakukan oleh Qian Liu (2020) menunjukkan bahwa terdapat 3 hal yang penting bagi perawat selama melakukan perawatan pada pasien COVID-19 yakni bertanggung jawab penuh atas kesejahteraan pasien, tantangan menangani 
pasien bangsal COVID-19 dan ketahanan di tengah tantangan. Selain itu hasil penelitian yang dilakukan oleh Fateme (2020) menyatakan bahwa pentingnya untuk menghormati martabat pasien, memberi dukungan komprehensif, dan damai dengan lingkungan selama proses perawatan. Perawat dalam melaksanakan pengabdian senantiasa berpedoman pada tanggungjawab yang pangkal tolaknya bersumber pada adanya kebutuhan terhadap perawatan untuk individu, keluarga dan masyarakat. Perawat dalam melaksanakan pengabdian dalam bidang perawatan senantiasa memelihara situasi lingkungan yang menghormati nilai budaya, adat istiadat dan kelangsungan hidup beragama dari individu, keluarga dan masyarakat. Perawat dalam melaksanakan kewajibannya bagi individu dan masyarakat senantiasa dilandasi dengan rasa tulus, ikhlas sesuai dengan martabat dan tradisi luhur keperawatan. Perawat senantiasa menjalin hubungan kerjasama yang baik dengan individu dan masyarakat dengan mengambil prakarsa dan mengadakan upaya kesehatan khususnya serta upaya kesejahtraan pada umumnya sebagai bagian dari tugas kewajiban pada kepentingan masyarakat (Haryono, 2012; Jaya, 2014). Selain itu, perawat diharuskan menggunakan alat pelindung diri yang lengkap dan melakukan psychological distancing ketika akan memberikan asuhan kepada pasien dan dianjurkan agara berkomunikasi tidak terlalu dekat, dimana kebiasaan perawat yang mengharuskan berkomunikasi dengan pasien harus terapeutik. Namun dengan semua hal yang terjadi saat ini terkait penanganan pasien COVID-19, perawat harus memperhatikan etik sosial dimana perlu dijunjung tinggi dan dipelihara agar hubungan dengan sesama tetap terjaga (Aditya Nurullahi, 2020).

\section{Tema 2 : Tantangan Etik Selama Perawatan}

Terdapat 2 studi yang membahas mengenai tantangan perawat selama proses perawatan dengan berbagai keluhan yang dialami pasien serta kebijakan dari setiap ruangan tempat perawatan. Studi tersebut menggunakan metode kuantitatif $(\mathrm{n}=2)$ yang dilakukan di Cina dan Iran. Penelitian Yuxiu (2020) menyatakan bahwa bentuk tantangan etik yang dihadapi perawat dalam merawat pasien COVID-19 adalah penemuan pertama yakni pasien dengan COVID-19 yang berbeda penangannya dengan pasien lainnya, terdapatnya ketidaksetaraan, tuntutan etika professional, dan kompetensi kerja. Penemuan kedua yakni pengontrolan, perencanaan dan pencarian 
dukungan agar fokus selama perawatan dan penemuan ketiga yakni munculnya dampak dari keteramilan keperawatan khusus, kemampuan penelitian ilmiah dan keterampilan manajemen. Hasil penelitian Naseri Salahshour bahwa salah satu bentuk tantangan etik pada perawat yakni hak pasien yang terlupakan, ketidaksetaraan, kurang perhatian pada etik professional dan dihadapkan pada situasi yang membingunkan. Semua fasilitas pelayanan kesehatan harus menerapkan kewaspadaan standar dalam memberikan pelayanan kesehatan yang aman bagi semua pasien dan mengurangi risiko infeksi lebih lanjut (Kementerian Kesehatan Republik Indonesia, 2020). Tingginya angka kejadian pasien yang terkonfirmasi COVID-19 menyebabkan kekurangan peralatan selama perawatan yang dibutuhkan dalam merawat pasien dan untuk melindungi tenaga kesehatan yang menjadi pemberi pelayanan kesehatan. Namun, anggota tim kesehatan berjuang untuk mempertahankan asuhan yang profesional, keseimbangan emosional, dan moral dalam situasi tragis pandemik korona (Centers for Disease Control and Prevention, n.d.; World Health Organization, 2020c).

\section{Tema 3 : Beban kerja selama perawatan}

Terdapat 6 studi yang membahas mengenai beban kerja yang dialami tenaga medis salah satunya adalah perawat yang menangani pasien COVID-19 dengan waktu yang lebih lama dan dengan berbagai bentuk gejala/keluhan. Studi tersebut menggunakan metode kuantitatif $(\mathrm{n}=5)$ yang dilakukan pada 3 negara yakni Cina, Denmark, Arab dan Perancis. Hasil penelitian Yuanyuan Mo (2020) menyatakan bahwa beban stress yang dihadapi para perawat selama menangani pasien COVID-19 terdiri dari perawat yang memiliki anak, jam kerja (shift) yang tidak menentu dan rasa kecemasan dengan nilai $\mathrm{p}$ value 0,05 yang berarti faktorfaktor diatas mempengaruhi beban kerja perawat selama perawatan. Selain penelitian yang dilakukan oleh Nicholas (2020) menunjukkan bahwa dari 906 petugas kesehatan yang berpartisipasi dalam survei, $48(5,3 \%)$ dinyatakan positif depresi sedang sampai sangat berat, 79 $(8,7 \%)$ untuk kecemasan sedang sampai sangat berat, $20(2,2 \%)$ untuk stres sedang sampai sangat-berat, dan $34(3,8 \%)$ untuk tingkat tekanan psikologis sedang sampai berat. Hasil penelitian Mohamad Hani (2020) menunjukkan bahwa perawat sering memiliki kekhawatiran yang tinggi untuk menularkan virus COVID-19 kepada keluarga dan teman dengan hasil 41,1\% lebih khawatir tentang COVID-19, 41,4\% 
sama-sama khawatir tentang MERS-CoV dan COVID-19, dan 17,5\% lebih tertekan oleh wabah MERS-CoV. Efek dari meningkatkan kasus COVID-19 di dunia membuat masyarakat salah satunya perawat menjadi cemas, takut serta panik sehingga melakukan penumpukan alat-alat medis secara pribadi, akibatnya tenaga medis yang menangani pasien COVID-19 secara langsung kekurangan pengadaan alat pelindung diri (APD). Tenaga medis khawatir tentang kekurangan peralatan pelindung dan perasaan tidak mampu ketika dihadapkan dengan pasien yang sakit kritis. Hal tersebut karena dibutuhkannya banyak APD untuk digunakan tenaga kesehatan dalam setiap harinya (Chen et al., 2020). Kasus penularan COVID-19 paling utama ditransmisikan melalui tetesan aerosol penderita dan kontak langsung dalam jangka waktu yang terlalu lama. Konsentrasi aerosol (tetesan cairan) diruang yang relatif tertutup akan berisiko tinggi terjadi penularan. Selain itu, masih kurangnya kemajuan dibidang teknologi membuat belum adanya alat yang dapat mendeteksi pasien terinfeksi virus corona atau sebaliknya (Chen et al., 2020). Pasien dengan COVID-19 dilakukan perawatan pada ruang isolasi, perawat dituntut tetap meminta pendapat kepada pasien terkait proses terapi yang akan diberikan meski wabah ini tergolong dalam kasus kesehatan yang darurat serta sepenuhnya menjaga kerahasiaan pasien selama perawatan (NHPCO Guide to Orgazational Ethics in Hospice, 2020). Perawat juga merasakan takut jika membawa virus COVID-19 ke rumah (Chen et al., 2020). Selain itu, ketakutan juga muncul saat masa inkubasi virus yang tidak pasti dan kemungkinan penularannya tanpa gejala (Monica, Arlington, \& Virginia, 2020).

\section{Pembahasan}

Tantangan etik biasa terjadi dalam praktik keperawatan klinis, dan lingkungan dengan penyakit menular yang menempatkan perawat berada di bawah tantangan etik dengan lebih mudah sehingga menyebabkan perawat mengalami masalah dalam mengontrol emosi dan tekanan psikologis yang dampaknya dapat merusak kesehatan mental perawat (Jia et al., 2020). Tantangan etik adalah hal yang umum terjadi dalam praktik keperawatan klinis (Rushton, 2016; Strandås \& Fredriksen, 2015). Tantangan etik mengacu pada dilema etika dan konflik etika serta skenario lain di mana harus ada pilihan yang sulit (Larkin et al., 2019). Dilema etika digambarkan sebagai situasi yang tidak dapat diselesaikan yakni keputusan yang dibuat antara dua orang dengan 
pilihan yang mungkin masuk akal secara moral, tetapi sama-sama bermasalah terhadap suatu keadaan (Kim, Oh, \& Kong, 2020). Lain halnya terhadap konflik etik muncul ketika seseorang menyadari perlunya tindakan yang tepat tetapi mengalami kesulitan dalam melaksanakan tindakan karena faktor internal atau eksternal tertentu (McGibbon, Peter, \& Gallop, 2010).

COVID-19 merupakan jenis peradangan paru yang disebabkan oleh infeksi virus corona. COVID-19 telah menyebar ke seluruh dunia sejak Desember 2019. Sekitar satu dari setiap lima orang yang terjangkit COVID-19 menjadi sakit parah dan mengalami kesulitan bernapas (World Health Organization, 2020b). Virus corona dapat ditularkan melalui tetesan, kontak dekat, atau udara melalui aerosol. Tenaga medis yang merawat orang dengan COVID-19 memiliki risiko tinggi terpapar COVID-19. Saat perawat merawat penderita pasien dengan COVID-19 akan tantangan etik yang ditimbulkan dengan mengobati penyakit menular sepert rasa ketakutan akan infeksi, hasil pengobatan yang mengecewakan, dan tingkat kematian yang tinggi (Jia et al., 2020).

Sekitar $68 \%$ yang menjadi garda terdepan merawat pasien COVID-19 adalah perawat. Untuk menahan wabah penyakit, ruangan khusus bangsal baru didirikan untuk memusatkan pasien yang semakin banyak. Kepedulian perawat pada pasien COVID-19 menghadapi kesulitan seperti lingkungan kerja yang asing, paparan penyakit, kurangnya pengalaman dalam pekerjaan yang baru, dan munculnya perhatian dari masyarakat umum dan media. Hal tersebutlah yang menjadi faktor munculnya tantangan etik pada perawat (Peter \& Liaschenko, 2013) sehingga dapat menyebabkan perawat tunduk pada emosi negatif (seperti kecemasan atau ketakutan) dan tekanan psikologis (seperti insomnia atau mudah tersinggung), merusak mental Kesehatan (KY \& X, 2017).

Pada kasus COVID-19 pasien yang dirawat sepenuhnya memberikan haknya kepada perawat atau tenaga medis yang menanganginya disebabkan kondisi pandamik ini berbeda jika dibandingkan dengan jenis penyakit lainnya, hal tersebut disebabkam pengobatan spesifik terkait COVID-19 belum ditemukan. Namun perawat pada prinsipnya harus melibatkan pasien untuk berpartisipasi dalam membuat keputusan etik atas tindakan yang akan dilakukan untuk pasien COVID-19 dan diperlukan komunikasi yang baik antara perawat dan pasien COVID-19. Melihat kasus pandemik yang sudah merugikan banyak aspek, sehingga 
pada prinsip autonomi bila terjadi kondisi gawat darurat sebelum pasien mengambil keputusan, pilihan yang bijaksana dalah memberikan perawatan sesuai standar (NHPCO Guide to Orgazational Ethics in Hospice, 2020). Masih kurangnya penelitian terkait penanganan pasien COVID-19 secara spesifik membuat perawat kewalahan dalam memberikan asuhan sehingga pelayanan yang diberikan sesuai dengan tanda-gejala yang ada pada pasien. Perawat kewalahan dalam menangani pasien ketika mereka tidak mau dikarantina di rumah sakit atau tidak bekerja sama dengan perawat/tindakan medis lainnya karena panik atau kurangnya pengetahuan tentang penyakit COVID-19 (Chen et al., 2020)

Perawat perlu mempertimbangkan posisi pekerjaannya dalam pembuatan suatu keputusan. Tidak semua keputusan pribadi perawat dapat dilaksanakan, namun keputusan pribadi perawat dapat dilaksanakan dengan keputusan/aturan tempat perawat tersebut bekerja. Namun, pada kasus COVID-19 menuntut perawat untuk menjadi garda depan dalam menghadapi pandemik ini. Perawat yang mengutamakan kepentingan pribadi sering mendapat sorotan sebagai perawat pembangkang sebagai konsekuensinya akan mendapatkan sanksi administrasi atau munhkin kehilangan pekerjaan (Jiang et al., 2020). Scema Of Physical and social Environmental nursing diagnose, memberikan penekanan terhadap kontaminasi, infeksi, dan kekerasan. Sehingga menjadikan perawat dan tenaga medis lainnya sangat berisiko tinggi tertular virus corona selain itu perawat memiliki kerangka kerja yang holistik dalam membuat penilaian tentang pengaruh lingkungan yang berkaitan dengan individu, keluarga, masyarakat, dan kesehatan global (Polk \& Green, 2007).

Meningkatnya kasus COVID-19 mengakibatkan meningkatnya pasien yang terinfeksi virus corona dan menjalani perawatan di rumah sakit, dibutuhkan kejujuran yang penuh dari tenaga medis kepada setiap pasien yang dirawat dengan COVID-19 disebabkan dengan berbagai penanganan yang diberikan secara spesifik seperti tidak diperbolehkannya keluarga untuk menemani dan hal lainnya yang membuat pasien banyak bertanya terkait dunia luar dan perkembangan kesehatannya (NHPCO Guide to Orgazational Ethics in Hospice, 2020). Tim perawatan kritis setiap harinya menghadapi tantangan moral dalam memberikan aktifitas pelayanan yang professional dalam menyikapi pandemik corona yang sedang terjadi (Savel \& Munro, 2015). Perawat merasakan adanya 
tanggungjawab profesionalisme yang mendorong untuk berpartisipasi dalam pencegahan dan penanggulan dari penularan COVID-19 (Sun et al., 2020). Perawat merasakan ketakukan saat pertama memasuki ruangan penyakit menular (Sun et al., 2020). Ketakutan itu semakin terjadi disaat tenaga kesehatan khususnya perawat melakukan perawatan pada pasien COVID-19 (Bao, Sun, Meng, Shi, \& Lu, 2020). Selain itu, perawat sebagai petugas kesehatan berisiko terinfeksi, membawa beban besar dalam perawatan klinis, dan upaya pencegahan penularan COVID-19 di rumah sakit maupun lingkungan sekitar (Bao et al., 2020). Dari hal tersebut menyebabkan munculnya stigma negatif dari masyarakat terhadap perawat sebagai garda terdepan yang dapat menularkan COVID-19 (InterAgency Standing Committee, 2020).

\section{Simpulan dan Saran}

Berdasarkan hasil temuan yang telah dilakukan dapat disimpulkan bahwa tantangan etik yang dihadapi perawat selama perawatan di masa pandemik COVID-19 yakni pasien dengan COVID19 yang berbeda penangannya dengan pasien lainnya, terdapatnya ketidaksetaraan, tingginya tuntutan etika professional, dan kompetensi kerja yang berubah-ubah. Selain itu hak pasien yang terlupakan, kurang perhatian pada etik professional dan perawat selalu dihadapkan pada situasi yang membingunkan. Perawat bertanggung jawab penuh atas kesejahteraan pasien, tantangan menangani pasien bangsal COVID-19 dan ketahanan di tengah tantangan disebabkan tinggi angka kejadian pasien terkonfirmasi sehingga menjadi salah satu faktor yang berhubungan terhadap penerapan konsep etik keperawatan selama proses penanganan pada pasien COVID-19.

\section{Daftar Pustaka}

AACN Position Statement. (2015). Moral Distress in Times of Crisis. American Journal of Critical Care, 24(4), 276278. Retrieved from https://doi.org/10.4037/ajcc2015738

Aditya Nurullahi. (2020). Ancaman Corona dan Etik Sosial. Retrieved 17 April 2020, from https://news.detik.com/kolom/d4923222/ancaman-corona-dan-etikasosial-kita

Bao, Y., Sun, Y., Meng, S., Shi, J., \& Lu, L. (2020). 2019-nCoV epidemic: address mental health care to empower society. The Lancet, 395(10224), e37-e38. Retrieved from 
https://doi.org/10.1016/S0140-

6736(20)30309-3

Centers for Disease Control and

Prevention. (n.d.). Interim Infection

Prevention and Control

Recommendations for Patients with

Suspected or Confirmed Coronavirus

Disease 2019 (COVID19) in

Healthcare Settings.

Chen, Q., Liang, M., Li, Y., Guo, J., Fei, D., Wang, L., ... Zhang, Z. (2020).

Mental health care for medical staff in

China during the COVID-19 outbreak. The Lancet Psychiatry, 7(4), e15-e16. Retrieved from https://doi.org/10.1016/S2215-

0366(20)30078-X

Haryono, R. (2012). Etika keperawatan dengan pendekatan praktis (Edisi 1). Jakarta: EGC.

Inter-Agency Standing Committee. (2020).

Catatan tentang aspek kesehatan jiwa dan psikososial wabah COVID-19 versi 1.0, (Feb), 1-20.

Jameton, A. (2017). What moral distress in nursing history could suggest about the future of health care. $A M A$ Journal of Ethics, 19(6), 617-628. Retrieved from https://doi.org/doi: 10.1001/amajethics.2019.78

Jaya, A. (2014). Etika dan hukum kesehatan (Cetakan 1). Sulawesi selatan: Pustaka As Salam.
Jeffrey, D. I. (2020). Relational ethical approaches to the COVID-19 pandemic. Journal of Medical Ethics, 46(8), 495-498. Retrieved from https://doi.org/10.1136/medethics2020-106264

Jia, Y., Chen, O., Xiao, Z., Xiao, J., Bian, J., \& Jia, H. (2020). Nurses' ethical challenges caring for people with COVID-19: A qualitative study. Nursing Ethics. Retrieved from https://doi.org/10.1177/09697330209 44453

Jiang, X., Deng, L., Zhu, Y., Ji, H., Tao, L., Liu, L., ... Ji, W. (2020). Psychological crisis intervention during the outbreak period of new coronavirus pneumonia from experience in Shanghai. Psychiatry Research, 1-3. Retrieved from https://doi.org/10.1016/j.psychres.202 0.112903

Kementerian Kesehatan Republik Indonesia. (2020). Pedoman Pencegahan dan Pengendalian Coronavirus Disease (COVID-19) (Maret 2020). Indonesia. Retrieved from

https://www.kemkes.go.id/resources/ download/info-terkini/COVID-19 dokumen resmi/REV-

04_Pedoman_P2_COVID-19_ 27

Maret2020_Tanpa TTD.pdf.pdf 
Kim, M., Oh, Y., \& Kong, B. (2020). Ethical conflicts experienced by nurses in geriatric hospitals in south korea: "if you can't stand the heat, get out of the kitchen". International Journal of Environmental Research and Public Health, 17(12), 1-13. Retrieved from https://doi.org/10.3390/ijerph1712444 2

KY, T., \& X, L. (2017). Influence of moral dilemma on job burnout of nurses in oncology department. Chin Nurs Res, 31(34), : 4344-4348.

Larkin, M. E., Beardslee, B., Cagliero, E., Griffith, C. A., Milaszewski, K., Mugford, M. T., ... Witte, E. R. (2019). Ethical challenges experienced by clinical research nurses:: A qualitative study. Nursing Ethics, 26(1), 172-184. Retrieved from

https://doi.org/10.1177/09697330176 93441

Markwell, A., Mitchell, R., Wright, A. L., \& Brown, A. F. T. (2020). Clinical and ethical challenges for emergency departments during communicable disease outbreaks: Can lessons from Ebola Virus Disease be applied to the COVID-19 pandemic? EMA Emergency Medicine Australasia, 32(3), 520-524. Retrieved from https://doi.org/10.1111/1742-

6723.13514

McGibbon, E., Peter, E., \& Gallop, R. (2010). An institutional ethnography of nurses' stress. Qualitative Health Research, 20(10), 1353-1378. Retrieved from https://doi.org/10.1177/10497323103 75435

Monica, S., Arlington, \& Virginia. (2020). Public mental health crisis during COVID-19 pandemic, China. Centers for Disease Control and Prevention, 26(7).

NHPCO Guide to Orgazational Ethics in Hospice. (2020). Ethical Framework for Decision Making in HPC During the COVID-19 Pandemic. Retrieved from https://www.nhpco.org/wpcontent/uploads/COVID-19-EthicalFramework-Decision-Making.pdf Peter, E., \& Liaschenko, J. (2013). Moral Distress Reexamined: A Feminist Interpretation of Nurses' Identities, Relationships, and Responsibilites. Journal of Bioethical Inquiry, 10(3), 337-345. Retrieved from https://doi.org/10.1007/s11673-0139456-5

Polk, L. V., \& Green, P. M. (2007). Contamination: nursing diagnoses with outcome and intervention linkages. International Journal of 
Nursing Terminologies and

Classifications : The Official Journal

of NANDA International, 18(2), 37-

44. Retrieved from

https://doi.org/10.1111/j.1744-

618X.2007.00048.X

Rubio, O., Estella, A., Cabre, L., Saralegui-Reta, I., Martin, M. C., Zapata, L., ... Amblas, J. (2020).

Ethical recommendations for a difficult decision-making in intensive care units due to the exceptional situation of crisis by the COVID-19 pandemia: A rapid review \& consensus of experts. Medicina Intensiva, 1-7. Retrieved from https://doi.org/10.1016/j.medin.2020. 04.006

Rushton, C. H. (2016). Moral Resilience: A Capacity for Navigating Moral Distress in Critical Care. $A A C N$ Advanced Critical Care, 27(1), 111119.

Savel, R. H., \& Munro, C. L. (2015). Moral distress, Moral Courage. Am J Crit Care, 24(4), 276-278. Retrieved from

https://doi.org/http://dx.doi.org/10.40 37/ajcc2015738

Strandås, M., \& Fredriksen, S. T. D. (2015). Ethical challenges in neonatal intensive care nursing. Nursing Ethics, 22(8), 901-912. Retrieved from

https://doi.org/10.1177/09697330145

51596

Sun, N., Wei, L., Shi, S., Jiao, D., Song, R., Ma, L., ... Wang, H. (2020). A qualitative study on the psychological experience of caregivers of COVID19 patients. American Journal of Infection Control, 000, 3-9. Retrieved from

https://doi.org/10.1016/j.ajic.2020.03.

018

van Nistelrooij, I., \& Leget, C. (2017). Against dichotomies: On mature care and self-sacrifice in care ethics. Nursing Ethics, 24(6), 694-703. Retrieved from https://doi.org/10.1177/09697330156 24475

World Health Organization. (2020a). Coronavirus Disease 2019 (COVID19) Situastion Report-73. Retrieved from 10.1056/NEJMoa2001316.4.

World Health Organization. (2020b). $Q \& A$ on coronaviruses (COVID-19), how does COVID-19 spread.

World Health Organization. (2020c). Rational use of personal protective equipment for coronavirus disease 2019 ( COVID-19 ). Interm Guidace, 1-7. Retrieved from WHO/2019nCov/IPC PPE_use/2020.1 